\title{
A Public Debate on Cyril of Alexandria's Views on the Procession of the Holy Spirit in Seventeenth-Century Constantinople: the Jesuit Reaction to Nicodemos Metaxas's Greek Editions
}

\author{
Nil Palabıyık ${ }^{1}$
}

Published online: 17 March 2020

(c) The Author(s) 2020

On a September afternoon in 1627, crowds gathered at the library of the Jesuit residence in Constantinople to witness a lively public discussion between two representatives of the Roman Catholic Church concerning Cyril of Alexandria's views on the procession of the Holy Spirit. ${ }^{1}$ It is interesting to see that a fifth-century church father's writings in the context of a dispute dating back to the sixth century were still considered politically relevant, socially influential and theologically compelling in seventeenth-century Constantinople. The primary aim of this rather ostentatious gathering was to adopt and promote a different (according to Eastern Christians an 'erroneous') viewpoint on Cyril of Alexandria's writings on the procession of the Holy Spirit, and thereby to present a counter-argument to that of the Eastern Church. The Jesuit dispute ultimately targeted the theological stance and the reputation of Cyril Lucaris (1572-1638), the ecumenical patriarch of Constantinople and the official head of the populous Greek Orthodox millet of the Ottoman Empire.

\footnotetext{
1 Cyril of Alexandria's opinion on this question is still controversial, but lies beyond the scope of this article. For a succinct overview, see A. E. Siecienski, The Filioque: History of a Doctrinal Controversy, Oxford, 2010, pp. 47-50.
}

\footnotetext{
I am grateful to Charalambos Dendrinos for his valuable comments on an earlier version of this article. I was funded by the Hellenic Institute of Royal Holloway, University of London in 20102014 when I carried out the major part of the research that led to this article. I also thank my current funder, Alexander von Humboldt Foundation, for their generous support, without which I could not have written this piece.

Nil Palabıyık

nil.palabiyik@manchester.ac.uk

1 The John Rylands Library, The John Rylands Research Institute, The University of Manchester, 150 Deansgate, Manchester M3 3EH, UK
} 


\section{Polemics on the Procession of the Holy Spirit and the filioque Dispute}

The debate on the procession of the Holy Spirit refers to the different wording of the Nicene Creed according to the Western and Eastern Churches. The Eastern Orthodox Church maintains that the Spirit proceeded from the Father, while the Roman Catholics added the phrase 'and the Son' — filioque in Latin — to the Creed in the sixth century during the Council of Toledo (589). In other words, the Western Church confesses a double procession of the Holy Spirit and the Eastern Church considers this a heresy. The filioque dispute occupied a central place in the polemics between these churches since the East-West Schism of 1054. Although still a hot topic of dispute in the seventeenth century, it is very likely that the filioque controversy was at the heart of the public discussion that took place at the Jesuit residence in Constantinople in September 1627 due to the appearance of a Greek Orthodox publication and its circulation in Constantinople at the time. The theological work in question was George Scholarios's first treatise on the procession of the Holy Spirit, a piece that heavily drew from Cyril of Alexandria's writings on the topic. ${ }^{2}$

Scholarios's work, composed in 1444/45, laid the theological basis for future polemics on the procession of the Holy Spirit between the Greeks and the Latins throughout the late Byzantine and post-Byzantine period. This long and highly influential treatise was written as a result of the meetings convened at the Imperial Palace in Constantinople between the Dominican Bartholomew Lapacci, the papal legate, and Scholarios before the latter became the first Patriarch under the Ottoman rule as Gennadios II (in office 1454-1465). ${ }^{3}$ The publication in question, which

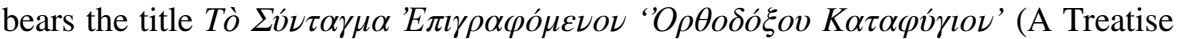
Entitled the 'Orthodox Refuge'), was the editio princeps of the work. It was edited and published around 1626 in London by Nicodemos Metaxas, a Greek monk from the Venetian-controlled island of Cephalonia. ${ }^{4}$ In June 1627, Nicodemos moved to Constantinople and established the first Greek printing house of the city. ${ }^{5}$ His cargo, transported by Royal Defense, a vessel that belonged to the English Levant

\footnotetext{
${ }^{2}$ A modern edition of the treatise is available in M. Jugie, L. Petit, and X.A. Siderides, Oeuvres complètes de Georges (Gennadios) Scholarios, II, Paris, 1929, pp. 1-268.

${ }^{3}$ G. Maloney, A History of Orthodox Theology since 1453, Belmont, MA, 1976, p. 94. On the patriarchal career of Scholarios, see M. H. Blanchet, Georges-Gennadios Scholarios (vers 1400 - vers 1472): Un intellectuel orthodoxe face à la disparition de l'empire byzantin, Paris, 2008. On his religious thought and interest in the writings of Thomas Aquinas, see C. Livanos, Greek Tradition and Latin Influence in the Work of George Scholarios: Alone against All of Europe, Piscataway, NJ, 2006.

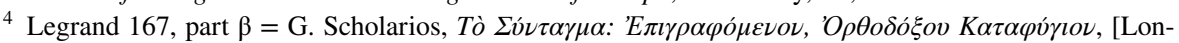
don, 1626]. All references to seventeenth-century printed Greek editions will follow the numbering system in E. Legrand, Bibliographie hellenique ou description raisonnée des ouvrages publiées par des Grecs au dix-septième siècle, 5 vols, Paris, 1894-1903.

5 On the Greek books Nicodemos Metaxas published in London and Constantinople, see N. Palabiyık, 'An Early Case of the Printer's Self-Censorship in Constantinople', The Library: Transactions of the Bibliographical Society, 16.4, 2015, pp. 381-404, with a complete list of his editions and the extant copies on pp. 401-4. On the reverberations of Nicodemos's printing activities in Venice and Venetian-controlled Greek islands, see L. Augliera, Libri, politica, religione nel Levante del Seicento: La tipografia di Nicodemo Metaxas, primo editore di testi greci nell'Oriente ortodosso, Venice, 1996; revised and translated

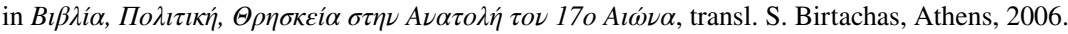


Company, consisted of crates of books he had printed in London and intended to distribute to the Greek Orthodox flock, and a printing press and Greek types to produce more books. ${ }^{6}$ It seems highly probable that the subsequent distribution and circulation of Scholarios's treatise in Constantinople incited the two disputants to pick Cyril of Alexandria and his stance on the filioque controversy as their subject matter rather than anything else.

\section{The Public Dispute and Its Aftermath}

A report by Jesuit father Jean Renier, written from exile in Chios on 14 April 1628, bears witness to the public discussion that took place in Constantinople the previous year about Cyril's views on the procession of the Holy Spirit. According to the report, the debate was held between Denis Guillier, the deputy abbot of the Jesuit mission, and the papal agent Kanakios Rossi in the presence of a Greek friar ${ }^{7}$ by the name of Ignatius and two other Greeks, oddly also named Kanakios. ${ }^{8}$ It was this event that led to a complaint by Lucaris to the șadāret $k \vec{a} i m-i$ makāme, the deputy to the grand vizier, which eventually resulted in the expulsion of Jesuits from the Ottoman Empire. Another report, dated 17 December 1627, from the French ambassador Philippe de Harlay, Comte de Césy (in office 1620-1631) to Louis XIII details the complaint put forward by Lucaris:

They [the Greeks] attacked the Jesuit fathers, along with Patriarch Lucaris, who, writing to the $k \vec{a} i m-i$ makām [Receb Paşa], openly declared that all four have contributed to the slander. ${ }^{9}$

De Harlay describes in dramatic terms how he feared for the Jesuits because of Lucaris's intervention and tried to keep them safe; they could have been taken at any moment, day or night, had it not been for his intervention. ${ }^{10}$

\footnotetext{
${ }^{6}$ On the technical aspects of Nicodemos's printing press, such as the equipment, typefaces, paper, ink and labour he employed, see N. Palabiyık, 'Redundant Presses and Recycled Woodcuts: The Journey of Printing Materials from London to Constantinople in the Seventeenth Century', The Papers of the Bibliographical Society of America, 110.3, 2016, pp. 273-98.

${ }^{7}$ When translating 'calogero' from Italian and 'caloyer' from French in reference to demotic Greek

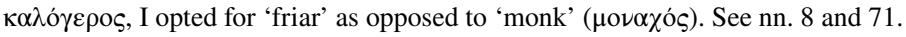

${ }^{8}$ Rome, The Roman Jesuit Archives (Archivum Romanum Societatis Jesu), Gallia, 95, report by Jean Renier from Chios, 14 April 1628, fol. 363 ${ }^{\mathrm{r}}$; published in G. Hofmann, Griechische Patriarchen und römische Päpste: Untersuchungen und Texte II.1: Patriarch Kyrillos Loukaris und die römische Kirche, Orientalia Christiana, 15.1 (52), Rome, 1929, p. 57-8: 'L'occasione di questa persecutione fù una conferenza fatta nella libraria nostra tra il P. Dionisio et il Signor Canaco gentilhuomo Greco al mese di Settembre dell'anno passato, in presenza d'un calogero detto Ignatio, et altri $\mathrm{d}<\mathrm{u}>\mathrm{oi}$ detti Canachi, et altri ancora. La materia della conferenza fù dell'opinione di S. Cirillo intorno alla processione dello Spirito Santo. Di questa conferanza uscirono i sopradetti tanto animati contra di noi, che si risolsero ad accusarci al caimacan o luogotenente del gran vezir, per esser noi perturbatori del riposo publico tra i Greci, anzi pretendevano far entrare insieme con noi nell' accusa i detti Canachi, per haver loro aiutato a questo negotio, e per così dire sforsato il Signor Canaco, ad accettare la disputa passata.'

${ }^{9}$ MS Paris, Bibliothèque nationale, fonds français 16150, report of Philippe de Harlay to Louis XIII, 27 December 1627, fol. $738^{\mathrm{r}}, 11.11-5$ : ' $\ldots$ ils ont attaqué les peres Jésuites et ont joint auec eux le Patriarche Cirille lequel sest le plus ouuertement declaré ayant donné par escrit au Caymacam ce que tous quatre ont pu contribüer de plus calomnieux...'.

${ }^{10}$ MS Paris, Bibliothèque nationale, fonds français 16150, report of Philippe de Harlay to Louis XIII, 27 December 1627, fol. 738, $11.4-6$ : ‘... mays Dieu ayant permis qu'un de mes surveillans maye donné cet advys je travaille maintenant a me défendre, et craygnanz que les peres ne soient pris ou la nuit ou a quelque heur...'.
} 
The complaint against the Jesuit fathers was followed by a counter-complaint by the Jesuits against the Greek printer Nicodemos, insinuating that he wanted to stir a rebellion among the Orthodox populations and had printed material attacking the Prophet Mohammed. This complaint resulted in the confiscation of the printing press by Ottoman officials on 6 January 1628 and led to the cessation of the activities of the printing house. Nicodemos was put on trial at the military court (in front of the $k \bar{a} z \bar{c}-$ 'asker) and found innocent. The verdict was confirmed by the highest civil authority, the şeyh-ül-islām Zakarīyā Yahyyā Efendī in a legally binding opinion $(f e t v \bar{a})$, which was summarized by a late-seventeenth century English scholar:

Opinions that go against the teachings of Muhammad are not necessarily acts of blasphemy, nor should they necessarily be considered as crimes. Since the Sultan has allowed Christians to profess their faith, they are not guilty for printing [these opinions] any more than they are for preaching them in public. Having different views does not make them liable to punishment, but only an infringement of the law. ${ }^{11}$

Fully cleared of his charges, Nicodemos was able to reclaim his press and printing materials but some of his equipment and, more importantly, his spirit was broken in the process. He soon left the city to take up the archbishop's throne in his native island Cephalonia and spent the rest of his life fairly uneventfully in the Ionian Islands.

After the confiscation of the Greek press, de Harlay proudly reported to the king that he had been successful in protecting the Jesuit fathers and ensured their future safety:

Having reported to Your Majesty in my last letter dated 28 December [1627] how the Jesuit brethren had been attacked, I shall now tell Your Majesty that despite their troubles, or to put it better, despite those here who cannot bear the greatness of Your Majesty, I believe that I have achieved this time that these good brethren are in the clear and need not live in fear any longer for their cause, as they did before. For if the $k \bar{a} i m-i$ makam [Receb Paşa] had followed the feelings and writings of him who persecuted them [Lucaris], they would have been thrown into the sea, in order that Your Majesty would have no choice but to suffer this act or to feel that it is somehow capable of changing the friendship which Your Majesty has with Lokmān, and which is unbearable for them. I shall not say any more on this subject, ... ${ }^{12}$

\footnotetext{
11 T. Smith, Collectanea de Cyrillo Lucario, Patriarcha Constantinopolitano, London, 1707, p. 106; J. M. Neale, A History of the Holy Eastern Church, The Patriarchate of Alexandria, 2 vols, London, 1847, II, p. 430, also translates this report by Smith, without, however, giving any reference to his source.

12 MS Paris, Bibliothèque nationale, fonds français 16153, report of Philippe de Harlay to Louis XIII, 10 January 1628, fol. $1^{\mathrm{r}}$, 11. 3-19: 'Ayant fait entendre à v[otre] M[ajes]te par ma dernière depesche du 28 de décembre comme les frères Jesuites avoient este attaques je luy diray maintenant que ... malgré leurs ennuys ou pour dire mieulx malgré ceuly qui ne peuvent suffrir icy la grandeur de v[o]t[r]e M[ajes]te je croy avoir obtenu que pour cette foys ... ces bons freres en seront quittes pour la peur quy restoit par leur cause, car sy le Caymacam eut suyvy les passions et les memoyres de ceuly quy les persecuta ... ils ... eussent este iettes dans la mer affin que de $\mathrm{v}[\mathrm{o}] \mathrm{t}[\mathrm{r}] \mathrm{e} \mathrm{M}[\mathrm{ajes}] \mathrm{te}$ soit ... reduite ou a comporter cette action ou a la ressentir en quelque maniere capable dalterer lamitié [qui] quelle a auec Lockman laquelle leur est insupportable, mays ie ne mestendray pas davantage sur ce subiect,...'.
} 
The sparing of the Jesuits, however, was not permanent. As we learn from an anonymous report allegedly written by a Greek, translated into French and preserved among the papers of de Harlay in Bibliothèque nationale de France, the Jesuits were deported to Chios in March 1628. ${ }^{13}$ The Jesuit fathers were 'shackled and sent to Chios on board a ship at midnight'. ${ }^{14}$ Kanakios Rossi was 'imprisoned with them' because he informed 'the Sacra Congregatio de Propaganda Fide on how one could destroy the Greek Church and banish Cyril [Lucaris] or assassinate him'. ${ }^{15}$ The prospects of Rossi at this point were bleak: 'For this reason all his goods were confiscated, and therefore quite a lot of people wonder whether he'll be strangled or thrown into the sea., ${ }^{16}$ De Harlay did not take all this lightly: he was 'furious by the ill treatment of Jesuits' and he 'threatened the Patriarch and the bailo of Venice'. ${ }^{17}$

\section{The Papal Intervention}

The historic background of the debate and the identities of the two disputants are as important as the theological content of the discussion. This is because tensions behind the public debate lie not only in the theological polemic around the filioque, but also in the controversy between the resident Jesuit fathers and the Greek Orthodox clergy. In early seventeenth century, Constantinople became a religious battleground where Pope Urban VIII waged a war against Patriarch Lucaris through his agents. The papal forces, particularly the missionary organization known as the Sacra Congregatio de Propaganda Fide (Sacred Congregation for the Propagation of the Faith) and the 'Protector of the East' Cardinal Bandini, ${ }^{18}$ were determined to remove Lucaris and replace him with a patriarch who would bow to the Roman doctrine. To this effect, several papal agents were sent to the Ottoman Empire. The arrival of one of these agents, that of Kanakios Rossi in Constantinople in 1625 with seven instructions set out by Cardinal Bandini distressed Lucaris greatly. Eventually, the patriarch sought refuge in the authority and advice of the English ambassador Sir Thomas Roe (in office 1621-1628). The instructions signed by Bandini and dated 21 February 1625 were thus registered in the cancellaria of the English ambassador

\footnotetext{
13 MS Paris, Bibliothèque nationale, fonds français 7161, anonymous report, 18 March 1628, fol. 203 . A note by a later reader on the right-hand side corner of the document reads: 'Ce memoire doit auoir esté ecrit par quelque heretique ou l'autre. (This letter must have been written by one heretic or another.)'

14 Ibid., fol. 203', 11. 3-12: 'Le Cahimachan apres auoir mis les Jesuites en un lieu incogneu sans que personne peust auoir accez pour les voir, il les a enfin le 18e du present faict conduire hors de la ville a minuit tous enchaisnez par sa compangie des gardes de deux cens turcs bien armez, et de la les a faict embarquer pour Chio en un nauire prepare a cette fin, en aiant donné la garde a quelques uns de ses plus confidens auec des commandements cachetez aux ministres de Chio ...'.

15 Ibid., fol. 203' ${ }^{\mathrm{r}}$, 11. 16-22: 'Le Grec Canacge Rossy qui auoit accoustumé de faire les allees et venues dici a Rome, est aussy prisonnier auec eux. Cest luy qui instruisoit la congregation Propaganda, par quelz moiens on pourroit destruire l'Eglise Grecque et chasser le Patriarche Cyrille ou le tuer.'

16 Ibid., fol. 203' , 11. 22-26: 'Et pour ce quon a confisqué tous les biens quil ouoit en ce pais, Cest ce quil faict doubter plusieurs quil pourra bien estre estranglé en chemin ou jetté en mer.'

17 Ibid., fol. 203ำ 11. 1-4: 'L'Ambassadeur de France est grandement offencé de ce mauuais traictement faict aux Jesuites menaceant le Patriarche et Aussy le Seigneur Bailo de Venize ...'.

18 Ottavio Bandini (1558-1629) was created cardinal in 1596. From January 1627 to July 1628, he participated in the negotiations with Patriarch Lucaris in an attempt to reconcile the Roman and Greek churches.
} 
at Lucaris's special request. ${ }^{19}$ The detail of the instructions, which criticized the many practices initiated and encouraged by Lucaris, shows how well-informed the Propaganda Fide was. In instruction number four, for instance, Bandini criticizes Lucaris for (1) sending young Greeks to study theology in England and Germany, (2) spreading 'heretical doctrines' through preaching and printing, and (3) trying to unite the Greek church with Protestant churches and entertaining the influence of 'Huguenot' ambassadors by not properly observing the Eucharist. ${ }^{20}$

I will briefly explore the three accusations against Lucaris by Bandini in order to reveal the degree of intelligence gathered by Rome. The first concerns the education of Greeks in England. In 1617, Patriarch Lucaris had arranged for one Metrophanes Critopoulos, who would later become patriarch of Alexandria, to be received by George Abbot, archbishop of Canterbury, and registered at Balliol College, Oxford. Metrophanes's tuition fees were paid through a scholarship offered by King James I. $^{21}$ After his studies in Oxford, Metrophanes travelled through the Low Countries and Germany visiting the reformed churches in the Continent. ${ }^{22}$

Metrophanes and Nicodemos were known to each other in London, ${ }^{23}$ and the former supported the latter's printing activities in various ways. First, Metrophanes acted as an intermediary between Nicodemos and Lucaris, who previously had no contact. According to the Venetian bailo Sebastian Venier's report, the manuscript sources for the books Nicodemos published in London were supplied by Lucaris via Metrophanes. On 4 September 1627, Venier wrote to the Venetian Senate:

... he [Nicodemos] told me that when he was in England the Greek patriarch here sent to his hieromónachos in London, who was studying there, a book

\footnotetext{
19 Thomas Roe, The Negotiations of Sir Thomas Roe, in his Embassy to the Ottoman Porte, from the Year 1621 to 1628 Inclusive, London, 1740, pp. 469-71.

${ }^{20}$ Ibid., p. 470: 4. 'Di lui siamo avisati, che nega l'invocatione de santi, il colto et veneratione de l'imagini et reliquie de santi, la preferenza reale de Christo dell' eucharista, la libertà del arbitrio, l'autorità de sacri concilii, le traditioni, l'autorita de santi padri, la necessita della confessione auriculare, et lo spiegare in esse li peccati della mente; et che in loco di lei havesse introdotto una certa confessione fatta a Dio publicamente, con parole generali; che manda li gioveni a studiare nelle università d'Inghilterra, et di Germania, dove s'insegna questa dottrina, per poter poi, per mezzo di loro, disseminarla per il Levante. Che a questa fine ha fatto stampare, et egli stesso dissemina, dandola alli vescovi, come catechesi piena di queste et simili errori, condonnati gia tanti anni fa, non solo dalla fede apostolica et dal concilio Tredentino, ma dalli suoi predecessori, ancora come egli stesso testifica nella professione della fede, lasciata tanti anni fa in mano del arcivescopo di Leopoli, riconoscendo questa et simile altri doctrine per heretiche, et dicendo che per questo era impossibile, che la chiesa Greca s'unisse mai con li Protestanti: che a contemplatione delli ambascitori Hugonotti, con li quali liberamente communica, ha tolto via sinodico, et ha lasciato di far riverenza alla santissima eucharistia.'

21 C. Davey, Pioneer for Unity: Metrophanes Kritopoulos (1589-1639) and Relations between the Orthodox, Roman Catholic and Reformed Churches, London, 1987, pp. 73-5.

22 Ibid., pp. 472-9.

23 See the letter from Metrophanes to his Oxford friend Matthias Turner mentioning a 'Greek Nicodemos' who intends to publish a work by the philosopher Theophilos Corydaleus in London, published

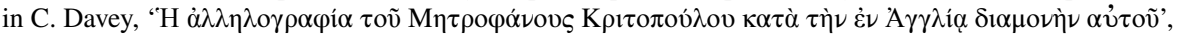
$\Theta \varepsilon o \lambda$ orí $, 41.1,1970$, pp. 123-5. The subsequent publication is Legrand $144=\mathrm{T}$. Corydaleus, $\Pi \varepsilon \rho \grave{l}$

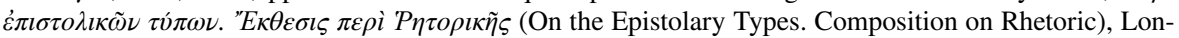
don, 1625 .
} 
by Saint Isidore, Bishop of Thessaloniki. ${ }^{24}$ [He also sent] one dealing with the Holy Spirit and Purgatory - controversial matters for us Catholics - by a famous Greek elder who was the patriarch of this city when it was taken by Sultan Mehmed [II] and who took part in the Council of Florence; ${ }^{25}$ and another [book] authored by one who studied in Padua ${ }^{26}$ and another [book] against the Jews composed by this patriarch. ${ }^{27} \mathrm{He}$ brought here these [books] in certain quantities along with the press that was extracted from that kingdom by a great favour... ${ }^{28}$

Metrophanes not only furnished Nicodemos with texts, but also helped him financially by purchasing a vast number of copies. We learn this from a note that Metrophanes penned before leaving Venice, which acknowledged the outstanding debt he owed to the Greek merchants George and Epiphanios Hegoumenos, arising from his purchase of Nicodemos' publications. ${ }^{29}$ The financial strain exerted on Metrophanes by this purchase and his lengthy stay in Venice is revealed by a letter he sent to Roe. He had been informed at a dinner party at the residence of Sir Isaac Wake, the English ambassador in Venice (in office 1624-1630), that Roe had acted as the protector of Lucaris and Nicodemos, and had defended Greek interests in Constantinople against the Jesuits. This pompous letter, which deliberately exaggerates the role Roe played in the expulsion of the Jesuits, ultimately aimed to earn the sympathy and financial support of the ambassador which would have enabled Metrophanes to leave Venice. The fact that he was still in the city two years after the composition of the letter suggests that his pleas for help fell on deaf ears. Despite its verbosity, the document is important for it exemplifies the negative sentiment

\footnotetext{
${ }^{24}$ Venier is mistaken here. Nicodemos did not publish any tracts by Isidore Glabas, Metropolitan of Thessaloniki from 1380-1384 and 1386-1396. He probably confused him with Gregory Palamas, who served as the Metropolitan of Thessaloniki from 1347-1359. See n. 34 for the relevant Palamas tract printed in London by Nicodemos.

${ }^{25}$ George Scholarios (Gennadios II, Patriarch of Constantinople) participated in the Council of Florence (1439), in which the Greek and the Latin churches tried to reach agreement on the doctrinal differences and end the schism.

${ }^{26}$ This could be Meletios Pegas, Maximos Margounios or Gabriel Severus, all of whom studied in Padua and were published by Nicodemos. See Palabıyık, 'An Early Case' (n. 5 above), pp. $402-4$.

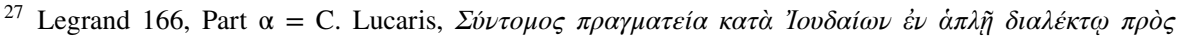
Гєஸ́ Constantinople, 1627.

${ }^{28}$ Venice, Archivio di Stato, Senato, Dispacci Constantinopoli 105/47, report of Venier to the Senate, 4 September 1627, fol. 68'; published in Augliera, Libri, politica, religione (n. 5 above), pp. 45-6: ' ... mi narrò come essendo egli in Inghilterra questo Monsignor Patriarca greco mandò in Londra ad un suo geromonico che ivi attendeva alli studij un libro di un Santo Isidoro che fu Vescovo di Tessalonica et di un tal secolare greco famoso che fu Patriarca di questa città quando se ne impatronì Sultam Meemet et intervene nel Concilio di Fiorenza, che trattano del Spirito Santo e del Purgatorio, materie controverse con noi altri cattolici, et in oltre una compositione di un tale che lungamente ha studiato in Padoa con un'altra compositione di questo Patriarca contro li hebrei; che di questi ne haveva portati seco certa quantità e che la stampa similmente per gran favore si era estratta da quel regno ....'.

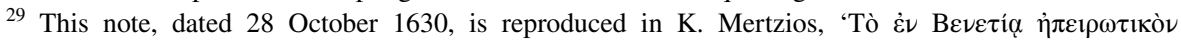

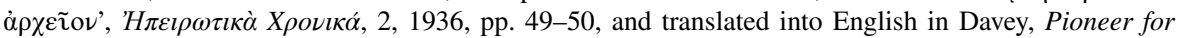
Unity (n. 21 above), p. 282.
} 
towards Jesuits among the Greeks and illustrates how threatened they felt by the Jesuit presence and activities in Constantinople and elsewhere:

Three days ago at dinner, the most illustrious ambassador of Britain already residing in Venice, who was present [at the table], unveiled your heroic deed against those in Constantinople who adulterate and distort the true doctrine, which was achieved not so long ago. [It was directed] against the Jesuits who, I think, are the destruction of the whole world, are full of lies and treacheries, and derive pleasure from the misfortune of others. They are the most cunning enemies of truth, false messengers, bent on glory and greed. They are a plague in all the provinces; they bring their tricks and snares to the Lord's vineyard. ... But, your most illustrious Excellency, I have heard the account of your illustrious and worthy deed. In fact, when I heard it, it brought so much felicity that I could scarcely express the great joy I felt, by the way, not only for myself and our most holy patriarch, but also for all of our Church which [needed] such a defender who appeared through divine providence in shining glory. For God is miraculous in His ways just as He was with Zerubbabel when he built the [Second] Temple in Jerusalem. Likewise today, Your Excellency wrought a miracle to the sole benefit of God, when he provided, produced, and supplied this godly work, which is as pleasing to the Lord as it is to faithful men, and especially the Greeks, thus bringing the expulsion of the Jesuits. ${ }^{30}$

It is likely that Rome monitored the education, activities and movements of Metrophanes from the moment he set sail for England until he left Venice.

The second complaint of Bandini concerns the publishing activities of the Greek church. Lucaris was very keen to utilize the powers of the printing technology to counter Roman propaganda. In a letter to the hégoúmenos Michael of Moscow (1613-1645), Lucaris reported that the Romans were printing theological tracts transmitting the writings of the holy fathers, 'but to these books, they [were] inserting their ungodly opinions, thereby distorting the writings of the holy and god-bearing fathers... Many Christians are appalled when they read the books written by the

\footnotetext{
${ }^{30}$ London, Public Record Office, State Papers, SP 97/14, letter of Metrophanes to Roe, 22 March 1628, fol. 258 , 11. 2-9 and 14-23: 'Nudius tertius, cum prandio, Illustrissimi Domini Magnae Brittaniae Legati Venetiis iam commorantis, interfui, in medium protulit, Heroicum opus, contra verae doctrinae adulteratores depravatoresque, Constantinopoli non ita pridem effectum et peractum fuisse; Jesuitas puto, qui

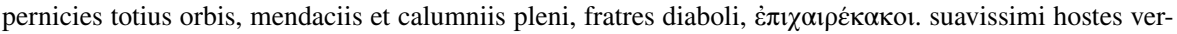
itatis, Pseudoprophetae, honoris et avaritiae cupidi sunt, cladem omnibus in provinciis magnam vineae Domini suis technis et insidiis adferunt. ... Hoc autem Illust[rissima] T[ua] Excell[entia] fecit, sicuti de hoc illustrissimo et laudatissimio opere narrare audivi: Re vera hoc cum audivi, ita me laetitia affecit, ut prae magno gaudio vix loqui potui, et ob id non modò mihi et sanctissimo Patriarchae nostro, verùm etiam toti nostrae Ecclesiae, quae talem protectorem, qui Dei providentiâ illuxit et illi apparuit. Quemadmodum enim Deus, (qui mirabilis in suis operibus) cum Zorobabel fecit, templo Hierosolymis aedificante: Ad eundem modum quoque hodiè illustrissimus Dominus miraculum singulari Dei beneficio fecit, edidit; dum Divinum opus, tàm Deo quàm hominibus piis imprimis Graecis gratum, praestitit, effecit, peregit, expulsis Jesuitis.' I have overlooked Metrophanes's infelicitous Latin and did not reproduce his cumbersome style in my translation.
} 
heretics. They believe that these were written by the holy fathers and are therefore drawn to and consumed by them. ${ }^{31}$

Despite the uneven balance of power between the Greek and the Roman churches, Lucaris believed that he had the upper hand, at least when it came to source material for publishing. After all, there were 'ancient books among the manuscripts of the monasteries of Mount Athos and elsewhere' transmitting the true writings of the fathers which could be utilized 'to foil their cunning'. ${ }^{32}$ One solid attempt to remedy the lack of printed books voicing the Greek Orthodox viewpoint was the establishment of Nicodemos's printing house in Constantinople.

As mentioned above, prior to his arrival in Constantinople, Nicodemos had published in London a treatise by Scholarios on the procession of the Holy Spirit. Two other works on the same topic by the fourteenth-century theologian Gregory Palamas and sixteenth-century scholar Maximos Margounios were issued together with Scholarios's tract, thus furnishing the Greek clergy with an indispensible compilation of texts on the subject written over the course of three centuries. ${ }^{33}$ In the errata section of the volume, Nicodemos explained in a note that the manuscript he initially

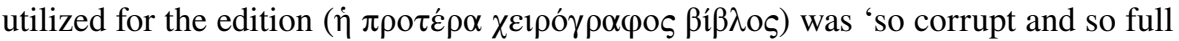

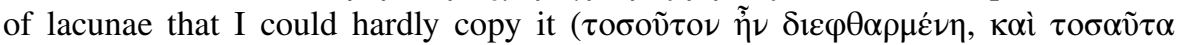

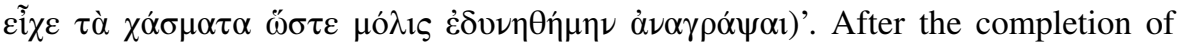

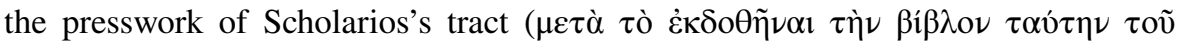

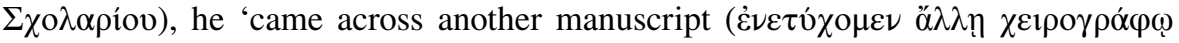
$\beta i ́ \beta \lambda \omega)$ ', which helped him draw the rather lengthy list of corrections and supply for the gap in the text between pages 30 and $31 .^{34}$ The gap was remedied by an insert of twenty-eight unnumbered pages that is found in in all surviving copies of the volume. ${ }^{35}$ The contents of the pages that were missing from the initial source is intriguing. Almost all of them deal with Cyril's arguments on the procession of the Holy Spirit, and Scholarios's refutation of the Latins through Cyril's writings.

It is not clear why and how this excerpt of twenty-eight pages suspiciously disappeared from the manuscript with which Nicodemos was supplied, but the replacement was exactly the type of authoritative text that Lucaris argued that can only originate from the libraries of the Eastern church. I have identified the correction copy that Nicodemos employed for the edition of Scholarios as London, Lambeth Palace Library, MS 461 owing to three elements: (1) the agreement between the text

\footnotetext{
${ }^{31}$ Quoted in C. Papadopoulos, Kú

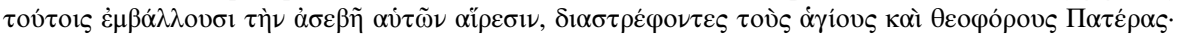

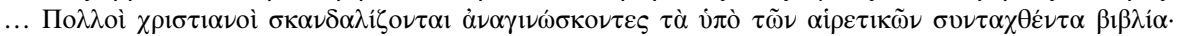

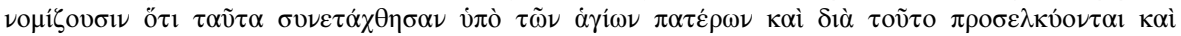

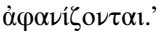

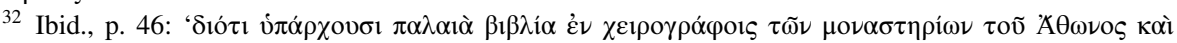

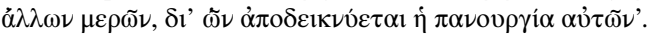

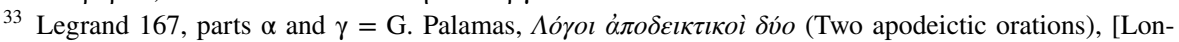

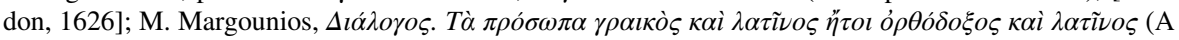
Dialogue between a Greek and a Latin) [London, 1626].

${ }^{34}$ Legrand 167 (nn. 4 and 33 above), sig. q1 ${ }^{\mathrm{v}}$, lines 1-9.

35 The British Library copy [shelfmark 1492.m.12.(2.)] has this section erroneously inserted between pages 22 and 23, instead of 30 and 31 .
} 
of the manuscript and the corrections made in the errrata, (2) the provenance of the manuscript and (3) the date when it entered the Lambeth collection. ${ }^{36}$ The oldest Greek manuscript in Lambeth Palace Library, MS 461 carries the autograph corrections and marginalia of Scholarios; it therefore transmits the most authoritative text of this tract. ${ }^{37}$ Its later provenance is equally impressive. MS 461 was once the prized possession of Lucaris's mentor Meletios Pegas, Patriarch of Alexandria (in office 1590-1601), as his monocondyle signature on fol. 1r (trimmed in the bottom margin) and autograph scholia indicate. The volume was passed on to Lucaris when he ascended the patriarchal throne of Alexandria and it moved with him to Constantinople afterwards. MS 461 came to Lambeth Palace in the early seventeenth century through the personal collection of Archbishop Abbot, who was engaged in a long-term correspondence with Lucaris. It appears that this volume was sent to Abbot by Lucaris as a token of friendship during or just before Nicodemos's sojourn in England.

Meanwhile the Propaganda Fide established its own press to publish books for the use of missionaries in the Orient and a wide distribution network to disseminate printed books. The Typographia Polyglotta of the Propaganda Fide published fortyfive books in Greek between 1628 and 1677, all aimed at strengthening the Roman position on issues that separated the two churches and persuading Eastern Greeks to follow Roman doctrine. Four of these books were already in circulation in 1628, the year Nicodemos's Greek printing house was active in Constantinople. ${ }^{38}$ They were (1) the Short Catechism (1597) of Cardinal Robert Bellarmine (1542-1621), written in dialogue form and translated into vernacular Greek with the title The Teachings of Orthodox Christianity without disclosing the name of its Jesuit author; ${ }^{39}$ (2) Louis

\footnotetext{
${ }^{36}$ There are only two extant manuscripts containing this text in British libraries. The other is Oxford, Bodleian Library, MS Barocci 92, which once belonged to the Venetian collection of the humanist Francesco Barozzi (1537-1604). The collection was brought to England in 1628 by the printer and bookseller Henry Featherstone, who acted as an agent for the Bodleian. In 1629 this substantial collection of Greek manuscripts was bequeathed to Archbishop William Laud (in office 1633-1645). The Barocci collection was subsequently purchased by William Herbert, Third Earl of Pembroke (1580-1630) and donated to the Bodleian Library. The well-documented history of this collection proves that it would have been impossible for Nicodemos to have access to this codex prior to his departure from England. Moreover the chapter headings and the errata corrections in the edition match the text of the Lambeth Palace Library codex.

${ }^{37}$ For catalogue description, see C. Wright, M. Argyrou and C. Dendrinos, A Descriptive Catalogue of the Greek Manuscript Collection of Lambeth Palace Library, Lambeth Palace Library and Hellenic Institute, Royal Holloway, University of London, London, 2016, published online at: https://www.royalhollo way.ac.uk/Hellenic-Institute/Research/LPL/Greek-MSS/Catalogue.pdf

${ }^{38}$ On the Greek books printed by the Propaganda Fide between 1628 and 1677 and their impact on the Greek communities of the Eastern Mediterranean, see Z. Tsirpanlis, 'I libri greci pubblicati dalla Sacra Congregatio de Propaganda Fide (XVII sec.)', Balkan Studies, 15 (1974): 204-224. The editions are listed in Legrand, Bibliographie héllenique. A list of relevant titles and their Legrand numbers are given in Tsirpanlis, p. 205.

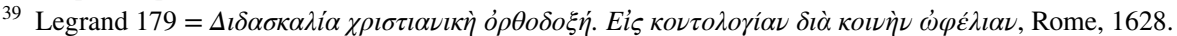
I inspected the copy in Florence, National Central Library, shelfmark 1253.3. This edition, with its direct style and simple language, was no doubt intended for use as a textbook at the Jesuit schools in Constantinople and Chios. The book consists of sets of questions on the basics of Christian belief asked by a teacher $(\delta เ \delta \alpha \dot{\sigma} \sigma \alpha \alpha \lambda \mathrm{o})$ and answered by a pupil $(\mu \alpha \theta \eta \tau \dot{\eta} \varsigma)$. Despite the title, the book strictly follows the Roman doctrine as is revealed very early on, on page 4, in the pupil's answer explaining the trinity of

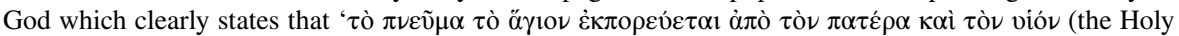
Spirit proceeds through the Father and the Son' [my emphasis].
} 
de Granada's Sinner's Guide (Guía de pecadores) translated into vernacular Greek by Andreas Rentios from Chios; ${ }^{40}$ (3) a narrative account of the Council of Florence by Johannes Mattheus Caryophylles (1565/6-1635), a Cretan who was educated in Rome and converted to Catholicism; ${ }^{41}$ and most importantly, (4) a counter-publication with the long title An Explanation of the Five Principle Points, contained in the declaration of the holy and ecumenical Council of Florence, once piously made, and translated into the vulgar language to help the common people. It was printed in Greek falsely under the name of Patriarch Gennadius. ${ }^{42}$ The same work, in which Scholarios purportedly defends the Roman doctrine on the issues that divided the two churches, was indeed printed in Rome in 1577 in Byzantine Greek with the title $\Sigma v \nu \tau \alpha \dot{\gamma} \mu \alpha \tau \alpha \pi \varepsilon \dot{\nu} \tau \varepsilon$ (Five Treatises). ${ }^{43}$ Its translator into vernacular Greek, Caryophylles, admitted that this treatise of unknown origin had been wrongly attributed to Scholarios in the Roman tradition, yet he defended the arguments found in the treatise, and maintained that it offered a correct interpretation of the writings of Cyril of Alexandria.

The Roman Explanation was clearly a counter-publication to Nicodemos's edition of the Orthodox Refuge, ${ }^{44}$ which, unlike the Roman treatise of the same title, transmitted the original work by Scholarios, collated with a manuscript with autograph corrections, as discussed above. The treatises published by Propaganda Fide's Typographia Polyglotta were, just like the majority of Nicodemos's publications, 'translated into the vulgar language to help the common people ( $\mu \varepsilon \tau \alpha \gamma \lambda \omega \tau \tau \imath 1 \sigma \mu \varepsilon \dot{\nu \eta}$

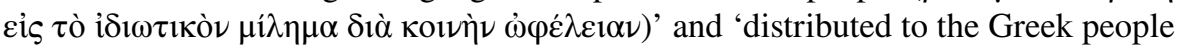

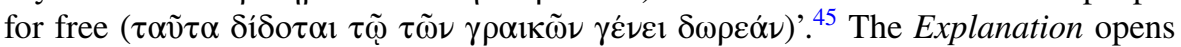
with a long letter to the reader by Caryophylles which presents 'the wise theologian

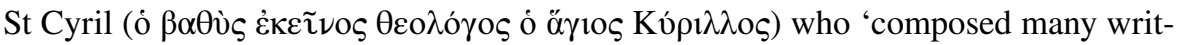
ings demonstrating the blasphemies of the foolish Nestorius during the Third Synod

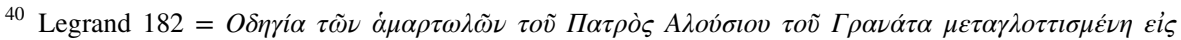

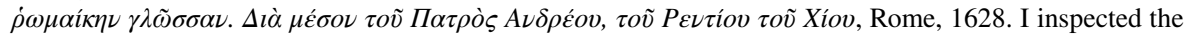
copy housed in Madrid, National Library of Spain, shelfmark U/3699.

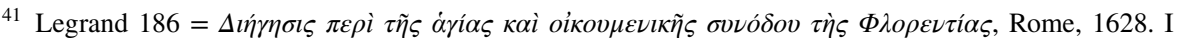
inspected the incomplete copy in Florence, National Central Library, shelfmark 711.1.

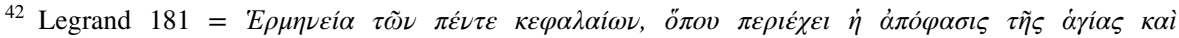

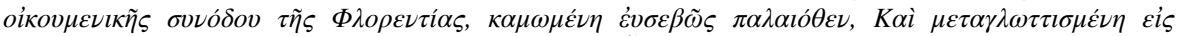

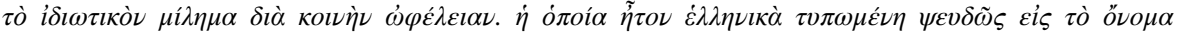

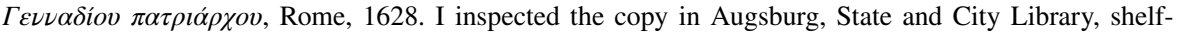
mark 4 Th Kv G 50.

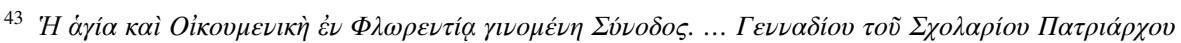

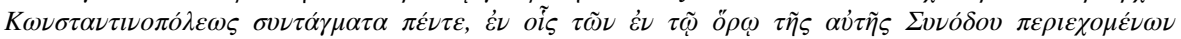

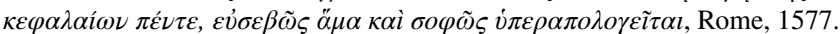

44 The title-page of Nicodemos's edition featured the long title of the first part (Т $\mu \tilde{\eta} \mu \alpha \Pi \rho \tilde{\omega} \tau o \nu)$ of the work which reads: 'On the Causes of the Schism in summary form, and that the proceedings of the Third Synod [i.e. the Ecumenical Council of Ephesus in 431] clearly prove that the Greeks hold correct

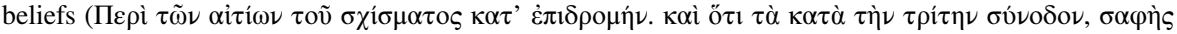

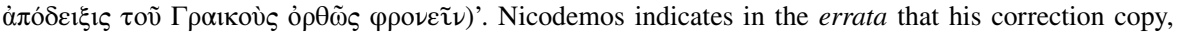

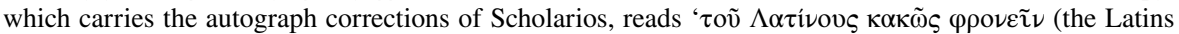

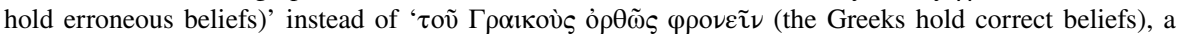
subtle but important difference.

45 Legrand 181 (n. 42 above), title-page recto and verso.
} 


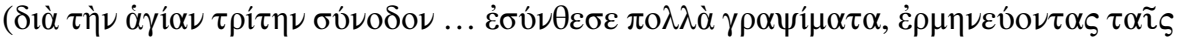

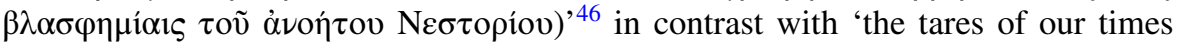

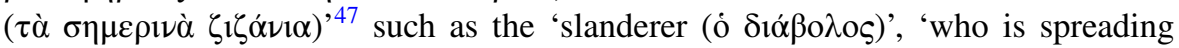
the teachings of the hateful Calvin (ó $\pi 0 \tilde{v} \sigma \pi \varepsilon \dot{\varepsilon} \rho \nu \varepsilon 1 \ldots$...

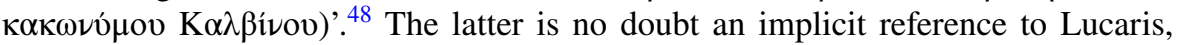
whereas the Explanation deals with the exact same issues addressed by Scholarios in the Orthodox Refuge and in the other treatises already published by Nicodemos. At issue are the five main doctrinal differences between the two churches: the Pro-

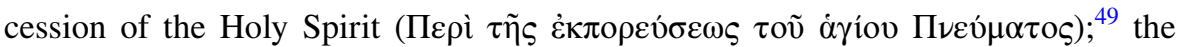

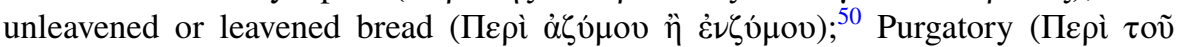

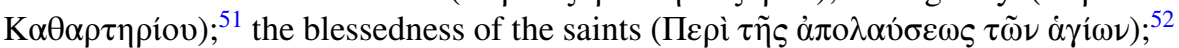

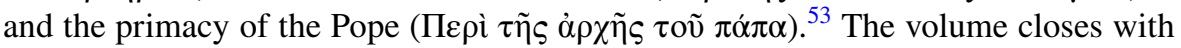
a vernacular Greek version of Cardinal Bessarion's encyclical letter to the Greeks under Turkish rule dated 27 May 1463. ${ }^{54}$ The letter warns Greeks of the East that 'deviating from the true beliefs' runs the risk of being 'the origin of the misfortune suffered by [the Greeks]'. 55 They must beware lest they be 'cut off from correctness' and 'separated from the universal church'. ${ }^{56}$ The choice of Caryophylles as editor and translator by the Propaganda Fide comes as no surprise. Educated at the Greek College of St Athanasius in Rome and appointed the Archbishop of Iconium (modern day Konya in Turkey) by the Pope, Caryophylles penned many works against the Greek Church. He was the author of a refutation ${ }^{57}$ of Nilus Cabasilas's On the Primacy of the Pope, a treatise published by Nicodemos in London; ${ }^{58}$ a refutation $^{59}$ of

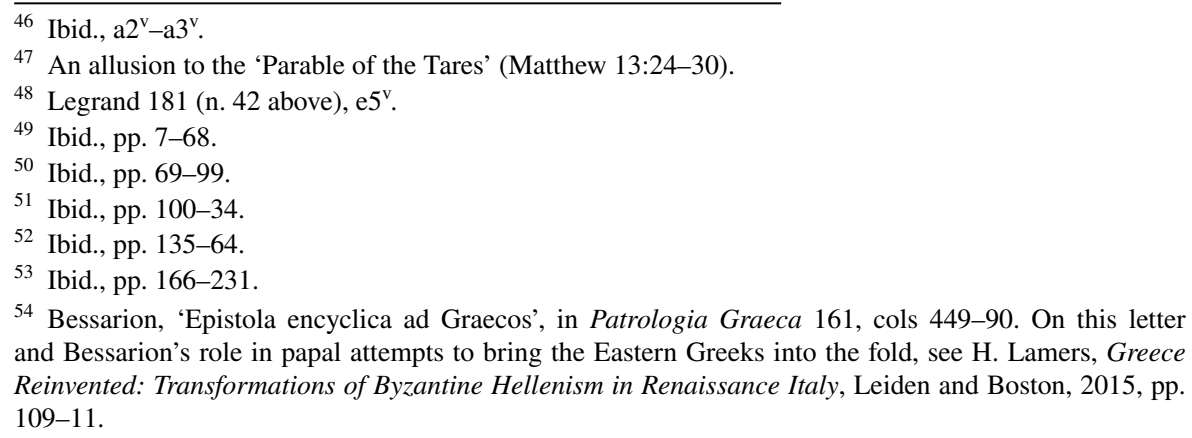

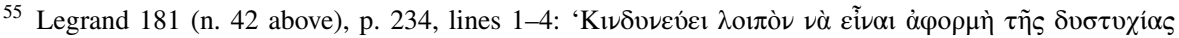

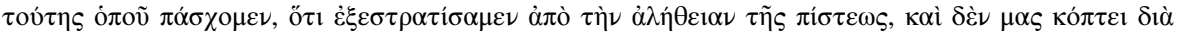

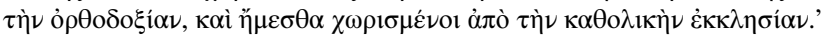

56 Ibid. Also quoted in Lamers, Greece Reinvented (n. 54 above), p. 128, n. 130, in which he discusses the nuances between the Greek originals and Bessarion's Latin translations of his writings intended for two different audiences.

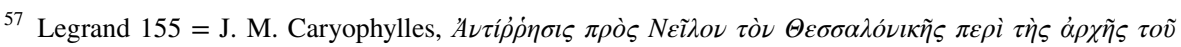
$\pi \alpha \dot{\pi} \alpha$, Paris, 1628. Caryophyllos's bilingual Latin and vernacular Greek text gives summaries of Nilus's chapters followed by his refutations. Published in Patrologia Graeca, 149, cols 729-878.

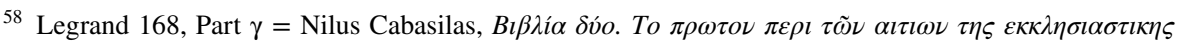
$\delta \imath \alpha \sigma \tau \alpha \sigma \varepsilon \omega \varsigma$. To $\delta \varepsilon v \tau \varepsilon \rho o \nu ~ \pi \varepsilon \rho \imath \tau \eta \varsigma \alpha \rho \chi \eta \varsigma \tau o v ~ \Pi \alpha \pi \alpha$ (Two Books. The First on the Causes of the Ecclesiastical Division. The Second on the Primacy of the Pope), [London, 1626], pp. 7-19.

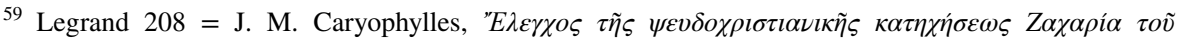

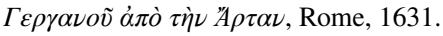


Lucaris's student Zacharias Gerganos's Catechism; ${ }^{60}$ and a counter-publication that branded Lucaris's 1629 Geneva Confession Calvinist propaganda. ${ }^{61}$

Another driving force in the battle for printed Greek editions was the pope's nephew, Francesco Barberini (1597-1679), who was created cardinal in 1623. Cardinal Barberini became one of the most important patrons of printed editions targeting the Greeks of the east and the doctrines of the Greek Church. His ambitious project of founding a Barberini Press to print Greek and Latin editions ultimately failed in 1638, but in the meantime, the Cardinal acted as a patron for vernacular Greek editions. ${ }^{62}$ His main publishing outlets were the Typographia Polyglotta and the Vatican Press, but his influence stretched as far as Naples, where he funded the printing of a treatise by the Augustinian friar Deodato Solera that attacked Lucaris. Solera envisioned Naples as a base for Roman missions to the Greek east. ${ }^{63}$

In addition to the enormous capital and human resources at the pope's disposal, the Jesuits of Constantinople also had the unwavering support of the French ambassador de Harlay. The Jesuits and the papal agents constituted a newly emerging group challenging the established authority of the Greek patriarch, the leader of the largest Christian denomination in the Ottoman Empire. They soon developed ingenious methods of navigating their way through the byzantine bureaucracy of the Ottoman state. Their first move was to keep a close eye on Nicodemos's activities in Constantinople. When he arrived in the city and submitted his goods to the Turkish customs to be checked, the Jesuits managed to steal some books and manuscripts with the help of a local officer. ${ }^{64}$ De Harlay ordered the Jesuits to scrutinize the books in order to find pretexts on the basis of which Nicodemos could be reported

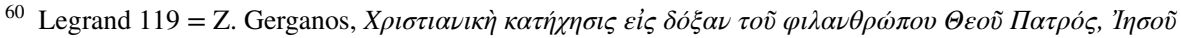

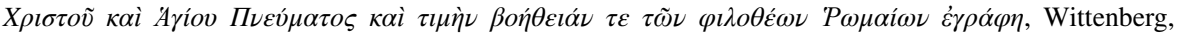
1622. In 1624, two years after the publication of the Cathecism, the French ambassador de Harlay sent to Rome a copy of the volume with this note attached: 'Christian catechism which Patriarch Cyril had printed at Wittenberg, under the name of one of his students named Zacharias, and had it distributed throughout that Empire (instruction chrestienne que le patriarche Cyrille a faict imprimer à Wittenberg, soubs le nom d'un de ses escholiers nommé Zacarye, et le faict distribuer par tout cet Empire)' (De Harlay to Louis XIII, 21 February 1624, MS Paris, BnF, fonds français 16150, fol. 239 ${ }^{\mathrm{r}}$. Nicodemos intended to print Gerganos's Exegesis of John the Supreme Theologian's Book of Revelation from an autograph manuscript which was sent to him while in England. The manuscript is now MS Oxford, Bodle-

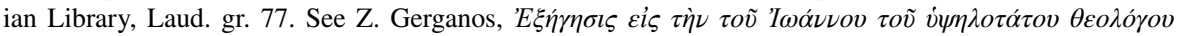

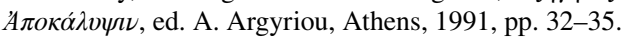

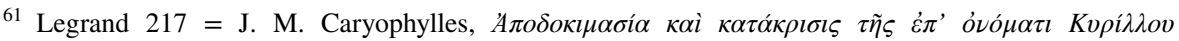

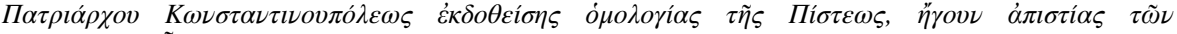

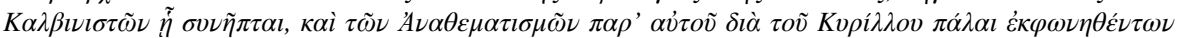

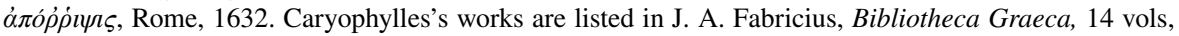

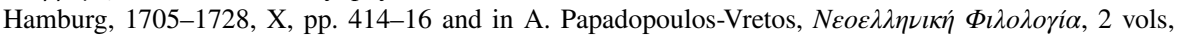
Athens, 1854-57, I, p. 204.

62 On Cardinal Barberini's printing activities, see P. Rietbergen, Power and Religion in Baroque Rome: Barberini Cultural Policies, Leiden and Boston, 2006, pp. 271-73 and 410.

63 On the strategic role of Naples in the missions to the Greek East, see P. A. Mazur, 'A Mediterranean Port in the Confessional Age: Religious Minorities in Early Modern Naples' in A Companion to Early Modern Naples, ed. T. Astarita, Leiden and Boston, 2013, pp. 215-34 (228-9).

64 Venice, Archivio di Stato, Senato, Dispacci Constantinopoli 105/47, report of Venier to the Senate, 4 September 1627 , fols $67^{\mathrm{r}}-71^{\mathrm{r}}$.
} 
to the Ottoman authorities. ${ }^{65}$ Having had the books inspected, de Harlay found what he wanted. He described the horrors he discovered in these 'heretical books' in the following terms:

... at the moment I am writing, the ambassadors of England and Holland ... are having printed here [books] that can poison the entire Great Eastern Church. Their aim is to add this venom to the ancient schism, so that it may put the wretched Greeks more at odds with the Church of Rome. ${ }^{66}$

In particular, the Jesuits were successful in identifying vitriolic comments against Islam in a treatise by Lucaris entitled Against the Jews. ${ }^{67}$ These comments allegedly printed by Nicodemos put him immediately in hot water. But the accusations of the Jesuits could never be substantiated because he had already censored the said passage and reprinted the relevant page before distributing the book. Therefore, the guilty passage, which was originally part of Lucaris's treatise and survives to this day in a manuscript copy, does not feature in the printed edition. ${ }^{68}$

The Jesuits not only monitored Nicodemos's printing activities, but also his sermons. The papal agent Rosis reportedly visited the patriarchal residence on 7 January 1628 to warn Lucaris against 'favouring and suffering Metaxas to preach, being a heretic and living in the house of a heretic [Roe], from whom they could expect nothing but opposition to the church of Rome. ${ }^{69}$ Such an intervention suggests that members of the Catholic faction were either attending the Mass at the Greek Church or had infiltrated the Greek congregation through informants in the community.

After education and the press, Bandini's third accusation regards Lucaris's close relations with the reformed churches. The patriarch did, indeed, keep regular correspondence with Dutch Calvinists Festus Hommius and Johannes Wtenbogaert, and later published a Confession which was considered by many to be Calvinist in doctrine. ${ }^{70}$ It was printed in Geneva in 1629 and led to his excommunication from the Orthodox Church posthumously in 1642. More could be said about the controversial figure of Lucaris, but his doctrinal allegiance to one denomination or the other is

\footnotetext{
65 G. Hering, Ökumenisches Patriarchat und europäische Politik, 1620-1638, Wiesbaden, 1968, pp. 165-7.

66 MS Paris, Bibliothèque nationale, Fonds français 16160, Letter of Philippe de Harlay to Jacques de Harlay, August 1627, fol. $137^{\mathrm{r}}-137^{\mathrm{v}}$, quoted in D. Harai, 'Une chaire aux enchères: Ambassadeurs catholiques et protestants à la conquête du patriarcat grec de Constantinople (1620-1638)', Revue d'histoire moderne et contemporaine, 58.2, 2011, pp. 49-71 (61): ‘... [1]es Ambassadeurs d'Angleterre et de Hollande ... font icy imprimés, à l'heure que je vous escris de quoy empoysonner toute cette grande Esglise d'Orient, avec intention que, ce venin estant joint à celluy de l'antien schisme, cela puysse rendre les pauvres Grecs plus irreconciliables avec l'Esglise Romayne.'

67 See n. 27 above.

68 For a comparison of the text of the original treatise and the printed edition, see Palabıyı, 'An Early Case' (n. 5 above), pp. 395-8.

69 Roe, Negotiations (n. 19 above), p. 763.

70 Lucaris's alleged Calvinist inclinations and his correspondence are treated in detail in G. Hadjiantoniou, Protestant Patriarch: The Life of Cyril Lucaris, 1572-1638, Atlanta, 1961. See also V. Tsakiris, 'The Ecclesiarum Belgicarum Confessio and the Attempted 'Calvinisation' of the Orthodox Church under Patriarch Cyril Loukaris’, The Journal of Ecclesiastical History, 63, 2012, pp. 475-87.
} 
beyond the aim and the scope of this article. Suffice it to say that Cardinal Bandini was not alone in attacking Lucaris's conduct. Similar criticisms were voiced by de Harlay in his private correspondence and his official reports. In December 1620, he wrote to Pierre Brulart, Secretary of State for Foreign Affairs to Louis XIII:

He was no sooner established than he began to spread the regrettable doctrines of Calvin and several other heresies which, from early on, informed the weak and ignorant souls of the poor Greeks, and the entire Eastern Church. Here are to be found six or seven ambassadors of Bohemia, Moravia, Silesia, Transylvania and the Prince Palatine whom Cyril invited to a holy feast along with the ambassadors of England and Holland, all of whom together attended the Mass sitting [which is against the Orthodox custom], and after the Gospel, when the Holy Sacrament was elevated and brought to them, they disrespectfully giggled. This caused a great scandal among all the Greeks who do not approve of their patriarch's affinity with these heretics, nor of the preaching of several friars who had recently studied at the University of Oxford in England, and at the University of Heidelberg were taking up positions in Constantinople and Galata. $^{71}$

Later, de Harlay shared his frustration over Lucaris's Calvinistic inclinations with Bandini in a letter dated 13 November $1627 .{ }^{72}$

\section{Attempts to Depose Lucaris}

De Harlay did everything he could to convert Orthodox prelates who were inclined towards Catholicism. It was he who managed to depose Lucaris in 1621 and attempted to replace him with Gregory, Metropolitan of Amasya, paying 20,000 thalers to this effect, which fell short of the pisskeş (regular payment) demanded by the sultan. ${ }^{73}$ Moreover, Gregory had not been canonically elected by the Holy Synod, therefore creating dissatisfaction among bishops and metropolitans. Lucaris's supporters finally nominated Anthemius II, Metropolitan of Adrianople, who agreed to leave his position to Lucaris for 40,000 thalers. This sum was allegedly provided by the English and Dutch ambassadors. ${ }^{74}$ Lucaris was able to reclaim the patriarchal

\footnotetext{
71 MS Paris, Bibliothèque nationale, fonds français 16160 , fols $141^{\mathrm{v}}-142^{\mathrm{r}}$, quoted in Harai, 'Une chaire aux enchères' (n. 66 above), p. 52 : 'Il ne fut pas plustost establi qu'il ne commancast à semer les malheureux dogmes de Calvin et plusieurs aultres Hérésies, lesquelles depuys ce temps-là n'ont pas manqué de se glisser dans les foibles et ignorants esprits des pauvres Grecs par toute l'Église d'Orient et se trouvant icy six ou sept Ambassadeurs de Bohesme, de Moravie, Silésie, Transylvanie et du prince palatin, ledit Cyrille convia à un festin solemnel lesdits Ambassadeurs avec ceulx d'Angleterre et de Hollande lesquels tous ensemble assistèrent à la messe dans des chayses, assis et couverts, et après l'évangile qu'on leur porta, ils firent à l'élévation du Saint Sacrement plusieurs actions de risée au grand scandalle de tous les Grecs quy ne pouvoient approuver cette affinité de leur Patriarche avec les Hérétiques non plus que les prédications de plusieurs caloyers religieux grecs lesquels venant d'estudier à l'université d'Oxford en Angleterre et à celle de Heidelberg remplissoient les chayres de Constantinople et Galata.'

72 MS Paris, Bibliothèque nationale, fonds français 7161 , fols $204^{\mathrm{v}}-205^{\mathrm{r}}$.

73 Harai, 'Une chaire aux enchères' (n. 66 above), p. 62.

74 Ibid., p. 55, quoted from J. Aymon, Monuments authentiques de la religion des grecs et de la fausseté de plusieurs Confessions de foi des chrétiens orientaux, The Hague, 1708, p. 207.
} 
throne within the same year of his deposition, but this came at a great deal of struggle and cost. De Harlay once again plotted against Lucaris in 1623 and offered the Ottoman authorities an equally large sum of 40,000 thalers. The Protestant-Orthodox faction was again more successful, for the English and Dutch ambassadors raised a sum of 45,000 thalers, which finally satisfied the Sultan. ${ }^{75}$ Lucaris triumphed once again, but this was a Pyrrhic victory at best: these never-ending struggles had put the Greek Church into no less than 120,000 thalers of debt by $1623 .{ }^{76}$

Showering officials with extravagant gifts was a centuries-old tradition in the city, as Roe observed 'Dollars are more weighty here, than reasons' ${ }^{77}$ Both Protestants and Catholics did not hesitate to spend enormous sums in order to keep Lucaris in office, or instead, to depose him. Each Ottoman sultan who ascended the throne would customarily pay a generous amount to the bureaucrats, officials and soldiers called 'throne ascension gratuity (cülūs bahşişi)'. In the six years spanning 1617 and 1623 when Mustafa I (reigned 1617-1618 and 1622-1623), Osman II (reigned 1618-1622), and Murad IV (reigned 1623-1640) occupied the throne respectively, the cülūs bahssissi had to be paid on all four occasions. Each cülūs (enthronement) ceremony had to be financed from the palace coffers in addition to the bahşiş distributed afterwards, which amounted to an average of 300 million akçes for each occasion. The court finances were so stretched and the treasury so empty by 1623 that Sultan Murad IV's cülūs bahşişi could only be paid by coins minted from melted gold pots, utensils and silverware from the palace. ${ }^{78}$ The political instability and the financial strain on the treasury no doubt made the Ottomans more willing to accept sums from foreign dignitaries and the Greek Patriarchate.

While the payment of the pisskeş and makt $\bar{u}^{c}$ (a lump sum) to the sultan was an official obligation of the patriarch, numerous other payments in the form of gifts to the grand vizier and other high ranking officials came to be expected. Opposing groups of Greek clergy recommended different candidates for the office and each rival faction was willing to offer more. So the incumbent of the patriarchal throne had to outbid any other potential candidate in order to keep the throne and the authority attached to it. The Ottomans indeed realized a considerable sum out of this struggle. For this reason, the Porte tolerated the quarrels between the Catholics and Protestants in Constantinople so long as it posed no threat to the security of trade and continued to line the pockets of the officials. In the larger scheme of things, this new divide offered the Empire an advantage both in foreign and internal politics, as good relations with the representatives could translate into alliances with their kings.

\section{The Jesuit Mission in Constantinople}

The root of the conflict between the Orthodox clergy and the Catholic missionaries in Constantinople witnessed in the debate of 1627 goes back to the point when the Jesuits arrived in the city and set up a school which attracted Greek pupils. The Jesuits had

\footnotetext{
75 Harai, 'Une chaire aux enchères' (n. 66 above), p. 57, quoted from Aymon, Monuments (n. 74 above), p. 209.

76 Roe, Negotiations (n. 19 above), p. 214.

77 Ibid., p. 352.

78 A. Özcan, 'Cülus', in Türkiye Diyanet Vakfi İslam Ansiklopedisi, 44 vols, Istanbul, 1988-2013, VIII, pp. 108-14.
} 
first attempted to settle in Constantinople in $1583 .^{79}$ They were based at the Church of St Benedict between the port of Karaköy and the district of Galata, the cosmopolitan quarter of Istanbul, where foreign diplomatic agents, clergymen, Genoese, Greek, Armenian and Jewish subjects and merchants, and European tradesmen ordinarily resided. This attempt failed owing to a plague epidemic that swept through Constantinople that year. Another group of fathers under the leadership of François de Canillac arrived in late 1609 and established a monastery and a school on the premises of the same church. Today, St Benedict is one of the handful of Catholic churches in Istanbul with an active congregation. Its school survived through various incarnations during the past centuries, currently operating as a prestigious private high school under the name Lycée St Benoitt.

At the time of the Jesuits's arrival in Constantinople, the Greek Orthodox Patriarch was Neophytos II (in office 1602-1603 and 1607-1612). ${ }^{80}$ Raphael II (in office 1603-1607), who occupied the throne between Neophytos's two terms, had shown an interest in Church union and even started a secret correspondence with Rome. Neophytos, now in his second term, continued in Raphael's footsteps by secretly sending a profession of faith to Rome. He reportedly wished to register his nephew at the Jesuit school and invited Catholic priests to celebrate the Eucharist at the Greek Church during Epiphany. ${ }^{81}$ Neophytos not only cultivated peaceful relations with the Jesuits but also promoted the union publicly. In the spring of 1611, a Greek Catholic priest from southern Italy preached a sermon openly advocating submission to Rome at the Church of St George, the main Orthodox cathedral of the city to this day, situated in the Phanar neighbourhood mainly populated by the Orthodox Greek community. Lucaris, Patriarch of Alexandria at the time, was asked by the Synod to preach a counter-sermon. Having seen the staunch opposition to Roman influence among the Greeks, Neophytos conceded to the Synod's demands and repudiated the Roman priest. ${ }^{82}$ Neophytos's successor, Timothy II (1613-1620), was yet another patriarch eager to build rapport with Catholics. ${ }^{83}$ He even sought the protection of the French ambassador de Harlay. De Harlay, in return, supported him for election to the patriarchal throne against Lucaris. The French ambassador, who maintained a 'secret' correspondence with Timothy II, found the patriarch very agreeable: 'a person of great piety and orthodox in doctrine' as opposed to the 'heretic' Lucaris who enjoyed the company of Protestant ambassadors. ${ }^{84}$ De Harlay went as far as to suggest that Lucaris instigated the poisoning of Timothy II at a dinner given at the

\footnotetext{
79 E. Legrand, Relation de l'établissement des P.P. de la Compagnie de Jésus en Levant, Paris, 1869, pp. 5-8; C. Frazee, Catholics and the Sultans: The Church and the Ottoman Empire, 1453-1923, Cambridge, 1983, pp. 67-103; E. Dursteler, Venetians in Constantinople: Nation, Identity, and Coexistence in the Early Modern Mediterranean, Baltimore, 2008, p. 146.

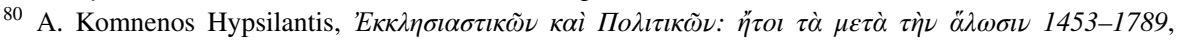
Istanbul, 1870, pp. 121-2.

81 Frazee, Catholics and the Sultans (n. 79 above), p. 82.

82 S. Runciman, The Great Church in Captivity: A Study of the Patriarchate of Constantinople from the Eve of the Turkish Conquest to the Greek War of Independence, Cambridge, 1968, p. 232.

83 The relations of these patriarchs with Rome have been fully explored, with the relevant documents, by G. Hofmann, Griechische Patriarchen und römische Päpste: Untersuchungen und Texte, Orientalia Christiana 47, 52, 63-64, 76, 84, 97, Rome, 1928-34.

84 Harai, 'Une chaire aux enchères' (n. 66 above), p. 53.
} 
residence of the Dutch resident in order to remove him. This allegation, like other accusations made against Lucaris by his many enemies, was never substantiated. ${ }^{85}$

The religious, theological, ecclesiastical and political divide is clearly marked in the writings of both the Greeks and the Latins. As mentioned above, to deprive Lucaris of the support of the Orthodox flock, the Jesuits and Rome spread the rumour that he was a Calvinist. On the other hand, Meletios Pegas, Patriarch of Alexandria and Lucaris's mentor, openly expressed his discontent with the Jesuit attempts to approach and ultimately convert the Greek Orthodox populations, for instance in Chios, the Aegean Island where the Jesuits were most active. In Constantinople in 1598, he wrote a letter to the metropolitan and the clergy of this island, that Nicodemos later printed in London. ${ }^{86}$ In it, Meletios speaks eloquently about his concerns regarding the Jesuits' various activities:

The children of the Church are taught by deceitful scholars (to say it as it is). Why, they even conduct baptisms through them! Funerals of the departed, visits to the sick, comforting the sad, helping the oppressed, various acts of support, sharing the Eucharist—we conduct all these through them! Many form a bond of fellowship because of the friendly attitude towards them. Soon there will be no hope left (if this is allowed to happen) that those who have been taken in by the constant deceit can be called back to recognize the truth. ${ }^{87}$

The amiable relations of the Greek community with the Jesuits continued at the cost of assimilation until Lucaris ascended the patriarchal throne.

During Lucaris's term, the services provided by the Jesuit fathers at the Church of St Benedict - conducted in Italian in the morning and French in the evening attracted large congregations. ${ }^{88}$ Their educational activities also proved extremely popular among the locals. ${ }^{89}$ Many Greeks, including monks, bishops and deacons, were attending lectures at the Jesuit College — indeed, they outnumbered the Catholic pupils ${ }^{90}$ — so much so that Lucaris was induced to circulate an encyclical advising the Orthodox to remove their children from Jesuit schools in order to protect their impressionable minds from potential 'heresy'. ${ }^{91}$

Jesuits provided free education in Italian and vernacular Greek that attracted large numbers of pupils from the resident communities. The curriculum spanned

\footnotetext{
85 Ibid., p. 53.

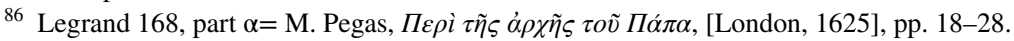

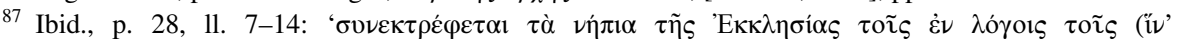

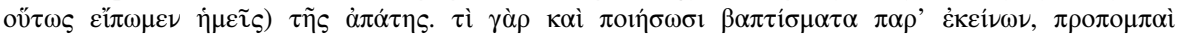

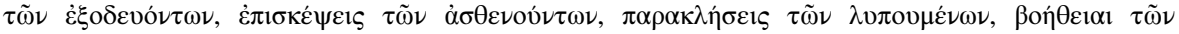

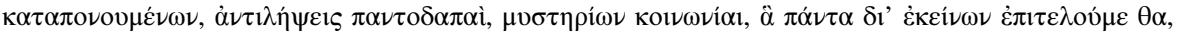

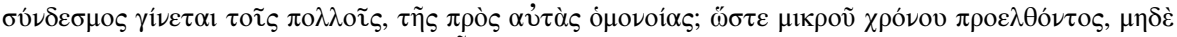

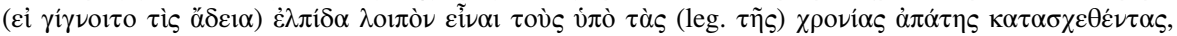

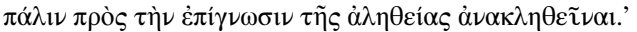

88 Frazee, Catholics and the Sultans (n. 79 above), p. 82.

89 E. Dursteler, 'Education and Identity in Constantinople's Latin Rite Community, c.1600', Renaissance Studies, 18.2, 2004, pp. 287-303 (298).

90 Ibid., p. 298.

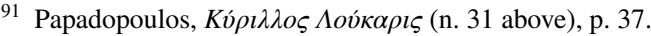


grammar, liberal arts and languages. ${ }^{92}$ As well as the regular classes, the Jesuits organized extra-curricular activities such as theatrical performances of mystery plays. These were popular among both the Catholics of Galata and the Greek Orthodox. Plays enacting the lives of early Christian martyrs or tragedies often portraying 'a sinner converted to Catholicism' were staged in vernacular Greek, and these dramatic genres thrived thanks to Jesuit efforts in the early seventeenth-century Levant. ${ }^{93}$ The themes and language of the plays make it clear that the Jesuit theatrical performances were aimed at the Greek-speaking population. A good example is the reported staging of a play about the childhood of St John Chrysostom in Constantinople on 13 November 1624, the very day the Orthodox celebrate the feast of the venerated saint. ${ }^{94}$ This particular play is tied intricately to the antagonism between Lucaris and de Harlay. The French ambassador's eight-year-old son, who grew up speaking Greek just like the other pupils, played the leading role, and he reportedly acted in such an admirable way that Lucaris requested to be invited to the performance to see him reciting the long and complex soliloquies in Greek. This seems extraordinary, given that the patriarch had strongly rebuked the Jesuit theatrical performances just a few years earlier, denounced them as unsuitable for a Greek audience, and warned parents against such 'traps' designed to lure Orthodox children to Jesuit schools. Lucaris's scepticism of theatre is not surprising in the light of the early church's stance against theatrical performances. Theatre continued to be frequently excoriated by the clergy throughout the Byzantine and postByzantine periods, starting with John Chrysostom. ${ }^{95}$ What is striking in this case is Lucaris's willingness to offer an olive branch to the Jesuits and de Harlay. His move to reinstate peaceful relations with the French in Constantinople, however, was not reciprocated. The resident consul of the Netherlands, the Venetian bailo and the ambassador of the Holy Roman Empire were all among the audience, yet the French ambassador refused to invite Lucaris and Roe to his son's school play. Very rarely in the history of drama did such an intimate and ordinary performance become the centre point of a diplomatic game between the great powers of Europe.

\section{Nicodemos Metaxas's Publications on the Procession of the Holy Spirit}

In the absence of an equally vivid account of the public dispute that is the subject of this essay, we can only project what the discussion might have entailed from Cyril of

\footnotetext{
92 Dursteler, 'Education and Identity' (n. 89 above), p. 299.

93 T. Krstić, Contested Conversions to Islam: Narratives of Religious Change in the Early Modern Ottoman Empire, Stanford, CA, 2011, p. 140.

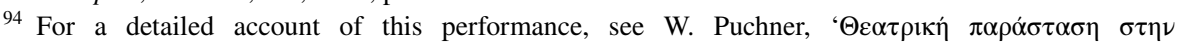

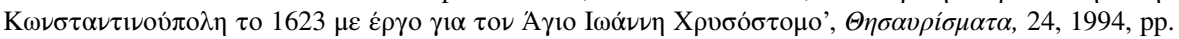
235-62. On Jesuit theatre in Constantinople during this period see, W. Puchner, 'Jesuit Theatre on the Islands of the Aegian Sea', Journal of Modern Greek Studies, 21, 2003, pp. 207-22; and more recently W. Puchner, 'European Drama and Theatre in Seventeenth-Century Istanbul', in Ottoman Empire and European Theatre I: The Age of Mozart and Selim III (1756-1808), ed. M. Hüttler and H. Weidinger, Vienna, 2013, pp. 223-34, and W. Puchner, Greek Theatre between Antiquity and Independence, Cambridge, 2017, pp. 196-245.

95 See his homily 'Against those who have abandoned the church and deserted it for hippodromes and

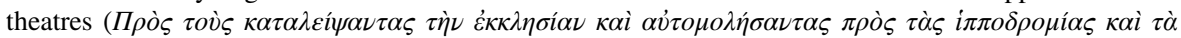

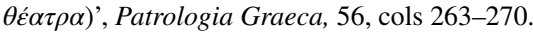


Alexandria's writings on the topic that were in circulation in the city at the time. This requires a brief look at the quotes chosen specifically by Scholarios and printed by Nicodemos at Lucaris's request. Even more important are those found on pages that have been removed from the original manuscript and later recovered by the publisher, since the major Greek accusation against the Latins is that they 'invent' new doctrines by 'altering' and 'corrupting' the writings of church fathers. Lucaris claimed to be on a mission to remedy these ill-conceived attempts through printing. The Eastern Church's primary concern in the seventeenth century, as made clear by almost every treatise Nicodemos published, was to 'preserve' the writings of the church fathers and to 'protect' these texts from the imminent threat of the Latin Church and their publications. One striking example is a passage quoted by Scholarios from Cyril's letter (no. 39) to John of Antioch which was also included in the decrees of the Council of Ephesus (431). Cyril writes:

We do not permit anyone in any way to upset the defined faith or the creed drawn up by the holy fathers who assembled at Nicaea as the times demanded. We give neither ourselves nor them the licence to alter any expression there or to transgress a single syllable, remembering the words: 'Remove not the ancient landmarks which your fathers have set'. For it was not they that spoke, but the Spirit of God and the Father, who proceeds from Him and who is not distinct from the Son in essence. ${ }^{96}$

This passage refers to the very argument put forward by the Latins in defence of the filioque, namely Cyril's statement that the Holy Spirit is essentially (ov่ $1 \omega \delta \tilde{\omega} \varsigma$ ) not different from the Son (oủ $\alpha \lambda \lambda \lambda$ ó $\tau \rho ı \nu ~ \tau o \tilde{~ Y i o v ̃) . ~ S c h o l a r i o s, ~ f u r t h e r ~ q u o t e s ~ C y r i l ~}$ in this respect: 'Hence the Spirit is also one and of one nature, and pours forth as if from a source from the Father; it is indeed not different from the Son' ${ }^{97}$ Yet, he adamantly claims that the Latins misinterpreted Cyril's words. ${ }^{98}$ In frustration, which was certainly shared by Lucaris and Nicodemos two centuries later in Constantinople, Scholarios asks:

\footnotetext{
96 Translation taken from Decrees of the Ecumenical Councils, ed. Norman P. Tanner, 2 vols, Washington, DC, 1990, I, p. 73 (with slight modifications). Excerpt is found in Legrand 167, part $\beta$ (n. 4 above),

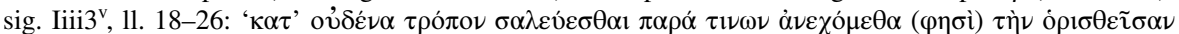

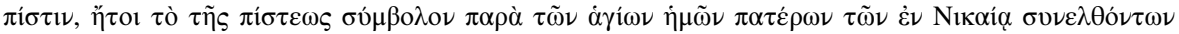

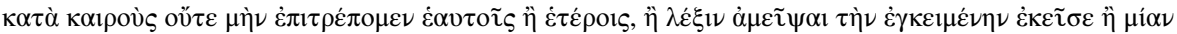

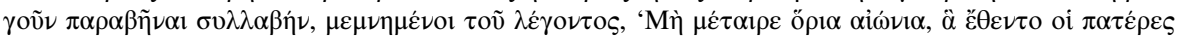

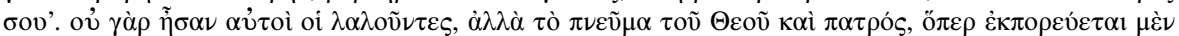

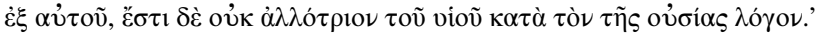

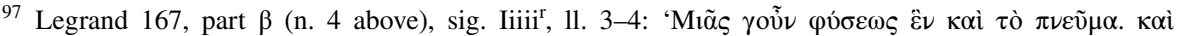

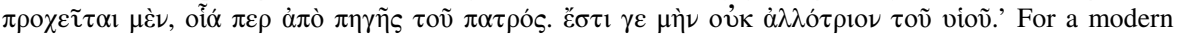
edition see, G.-M. de Durand, Cyrille d'Alexandrie. Dialogues sur la Trinité, 3 vols, Paris, 1976-8. Available through, http://stephanus.tlg.uci.edu/Iris/Cite?4090:023:566217.

98 For a critical edition of a similar treatise refuting the 'errors' of the Latins by the fourteenth century theologian Matthaios Blastares, see K. Palaiologos, 'An annotated edition of the Refutation of the Errors of the Latins by Matthaios Blastares', PhD diss., University of London, 2011, especially pp. 37-8 discussing how Blastares used Cyril of Alexandria's words to discredit the Latin arguments.
} 
Where exactly does Cyril say that the Spirit has its existence from the Son, or from the Father and the Son at the same time? Or that the Spirit proceeds from the Father and the Son, or that the Son is the origin of the Spirit? Or the cause of the existence of the Spirit? Or that [the Son] is simply the cause of the Spirit? So, is it to be trusted that this is Cyril's good opinion and that of the whole Eastern Church? ${ }^{99}$

The need to express the Greek Orthodox position regarding the focal doctrinal point of divergence between the two churches, the addition by the Latins of the filioque clause to the Creed, resonated strongly with Lucaris and his close circle at the time of the discussion. The Jesuits had no desire to move an iota from Rome's standpoint, even in order to appeal more to their Greek audiences. They rather preferred to reinterpret the Alexandrian father and cling onto scraps of evidence that he agreed with the filioque clause, even though Cyril of Alexandria's writings predate the EastWest schism and the escalation of the filioque controversy.

\section{Conclusions}

The sheer amount of money, effort and human resources that went into establishing one viewpoint over the other both by the pope and the patriarch demonstrate that there was more at stake than theological concerns. The writings of the church fathers remained relevant centuries after their composition and were utilized both in print and in oral debates to influence public opinion and to win political battles. Cyril of Alexandria's writings in particular contain a number of passages in which he talked about the Holy Spirit proceeding from or through the Son. Both Latins and Greeks later used these passages to prove or disprove that it is right to add the filioque to the Nicene Creed. Although the social, religious and political framework of seventeenth-century Constantinople was very different from that of fifth-century Alexandria, Cyril's opinions still carried so much weight and commanded such authority that they became a popular and effective propaganda tool for both the Eastern and the Western church.

The irreconcilable divide between the Latin and the Eastern churches, namely whether the Holy Spirit proceeded from the Father alone according to the Greek theologians, or from the Father and the Son according to the Latin doctors, could not be remedied either by peaceful negotiation or by fierce conflict. It is obviously not for a historian to take sides in such a conflict. The Greeks felt that the Jesuits used underhand techniques to ingratiate themselves with the local population and ultimately deceived them. The Propaganda Fide printed catechisms and other textbooks in the Greek vernacular which contained their own theological interpretations, even when they were clearly at odds with that of the Eastern Church. They hid the authorship of these texts by not printing the author's name on the title page, but rather claiming there that they contained 'orthodox' doctrine. One can see why the Greek clergy complained about this. This approach did not foster ecumenical understanding.

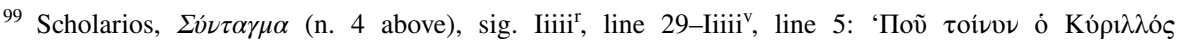

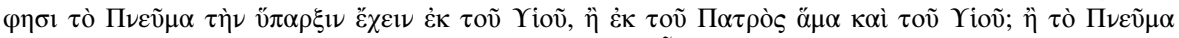

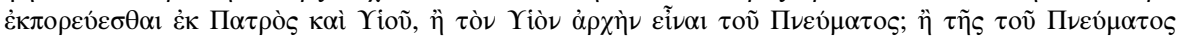

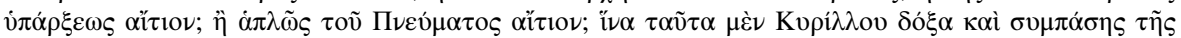

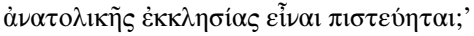


In the end, no publication nor public dispute was powerful enough to establish the true meaning of the writings of the early church fathers. No conciliation between the Latins and the Greeks with regards to the filioque clause could be achieved. Instead, in Constantinople during the early seventeenth century, dispute around the interpretation of the church fathers eventually led to the destruction of both factions. The Greek press of Constantinople, an important outlet for the dissemination of Orthodox theological tracts, ceased activity abruptly in January 1628 due to the complaints of the Jesuits. The owner of the printing house, Nicodemos Metaxas, had been publishing tracts in order to put forward the Greek stance on various issues that divided the two churches such as the procession of the Holy Spirit, the primacy of the pope, purgatory, original sin, and the sacrament of the Eucharist for members of all denominations to read. According to his own account of events, all he intended to do was to open a platform for discussion. As he makes clear in the lengthy and philosophical preface he appended to the edition of Scholarios, his main aim was to defend the 'truth' $(\dot{\alpha} \lambda \dot{\eta} \theta \varepsilon \imath \alpha)$ in the face of all adversities while transmitting the true word of the Scriptures and the teachings of the early church fathers. To this effect, Nicodemos published tracts in vernacular Greek as much as possible. ${ }^{100}$ This open and democratic approach, unfortunately, did not resonate with his readership in Constantinople. The Greek clergy and the community were too divided to show solidarity and support for the first attempt to found a Greek publishing house in the Ottoman capital, whereas the Jesuits felt antagonized by its activity and perceived it as a threat to their mission.

In a similar fashion, the Jesuit fathers were banished in March of the same year as a result of the complaints from Lucaris, who considered their existence a threat to his own. The Jesuit school attached to the St Benedict Church, an important centre for vernacular learning and cultural activity for both the Latin and Greek communities, was shut down. The Patriarchate, having lost its printing press and accumulated substantial debts, benefitted very little from the departure of the Jesuit mission.

All that is left to posterity after this damaging patristic fracas is a handful of reports relating the public discussion on the filioque question that took place on a September evening in the Jesuit library in Constantinople. The first and only early modern edition of Scholarios's treatise printed by Nicodemos, however, survives in sixteen copies worldwide. The circumstances of the editing and printing of Scholarios's Orthodox Refuge in London and the reverberations of its circulation in Constantinople demonstrate the importance of Greek sources in reconstructing patristic scholarship in the east as well as the west.

Open Access This article is distributed under the terms of the Creative Commons Attribution 4.0 International License http://creativecommons.org/licenses/by/4.0/), which permits unrestricted use, distribution, and reproduction in any medium, provided you give appropriate credit to the original author(s) and the source, provide a link to the Creative Commons license, and indicate if changes were made.

Publisher's Note Springer Nature remains neutral with regard to jurisdictional claims in published maps and institutional affiliations.

${ }^{100}$ For a discussion of this preface, see Palabıyı, 'An Early Case' (n. 5 above), p. 385. 